\title{
Paulo da Gama e os narradores em Os Lusíadas, de Luís de Camões
}

\author{
Leni R. Leite \\ Universidade Federal do Espírito Santo/Fapes \\ Paulo R. Sodré \\ Universidade Federal do Espírito Santo
}

\begin{abstract}
Resumo: Considerando as reflexões de Cleonice Berardinelli sobre os narradores de Os lusíadas, de Luís de Camões, discutimos aspectos da estrutura narrativa dessa epopeia a partir da observação do narrador Paulo da Gama em cotejo com a atuação do narrador épico e do narrador-personagem Vasco da Gama. Propomos uma revisão das conclusões sobre o papel narrativo de Paulo da Gama no poema, considerando-o como o segundo narrador-personagem e, por conseguinte, o terceiro narrador em importância na arquitetura narrativa camoniana, de acordo com os objetivos expostos pelo autor na proposição do canto épico português. Hernâni Cidade, Jorge de Sena e Vítor Manuel de Aguiar e Silva conduzem, sobretudo, os argumentos expostos.
\end{abstract}

Palavras-chave: Os Lusíadas; Luís de Camões; estrutura narrativa; narrador épico; Paulo da Gama.

\begin{abstract}
Taking into consideration Cleonice Berardinelli's writings about the narrators of The Lusiads, by Luís de Camões, this paper discusses aspects of the structure of this epic poem's narrative, by observing Paulo da Gama as a narrator, in comparison with the epic main narrator and Vasco da Gama as character-narrator. It also proposes a revision of the reached conclusions about Paulo da Gama's narrative role in the poem, considering him a second character-narrator and, therefore, the third narrator in order of importance in Camoes' narrative architecture, according to the author's proposition in this Portuguese epic poem. Hernâni Cidade, Jorge de Sena and Vítor Manuel de Aguiar e Silva are specially used to build the argument.
\end{abstract}

Keywords: The Lusiads; Luís de Camões; narrative structure; epic narrator; Paulo da Gama.

Desde a leitura de um estudo fundamental para a compreensão da estrutura da epopeia camoniana, assinado por Cleonice Berardinelli, “Os excursos do Poeta n’Os Lusíadas" - originalmente publicado em 1972 e republicado em edição revista e ampliada de 2000 -, chamou-nos a atenção a compreensão do papel secundário ou eventual de Paulo da Gama nessa estrutura.

Berardinelli examina as diversas vozes que compõem a narrativa de Camões, esclarecendo, na altura, a identificação e a função das principais vozes do texto: a do Poeta (em primeira pessoa, 
a expor a proposição, o encarecimento, as invocações, a dedicatória, além das diversas reflexões, exortações e queixas ao longo do poema), a do Narrador (narrador épico propriamente dito, heterodiegético ou onisciente), Narrador ${ }_{2}$ (narrador homodiegético e autodiegético, Vasco da Gama $^{1}$ ) e "narradores eventuais: Veloso, Paulo da Gama, a falar do passado; Júpiter, a Ninfa e Tethys, do futuro [...]" (BERARDINELLI, 2000, p. 32-33; grifo nosso).

Em outro estudo do mesmo ano, "A estrutura d'Os Lusíadas" ([1972] 2000, p. 15-30), Berardinelli chega a mencionar, em nota, Paulo da Gama como um terceiro narrador - "N" ${ }_{3}$ (p. 18) -, antecedido pelo "primeiro Narrador" ("N, $\mathrm{N}_{1}$ ) e pelo segundo, Vasco da Gama ("N ${ }_{2}$ "), ao lado dos narradores da história futura, Júpiter, Ninfa e Tétis. Contudo, o terceiro narrador é praticamente esquecido como tal na sequência do estudo. Percebe-se, assim, que no artigo sobre os excursos - "reflexões, exortações, queixas" (BERARDINELLI, 2000, p. 33) - a autora mantém sua compreensão de que há dois narradores importantes, tornando os outros apenas eventuais, como vimos.

Em estudos anteriores e posteriores, tende-se a perceber o papel do irmão do herói português do mesmo modo. Para Hernâni Cidade, no clássico Luís de Camões: o épico, Paulo da Gama é aquele personagem que apresenta "toda uma galeria de guerreiros" (1968, p. 167-168), isto é,

Uma galeria formada pelas bandeiras que de cada herói apenas ilustrassem a acção de mais relevo e de que o cicerone que as mostrasse se contentasse de em breves palavras indicar os traços essenciais, seria o adequadíssimo processo. [...] As figuras, porém, que as bandeiras representam não são os reis (abre-se excepção para D. Afonso Henriques, por quem o Poeta mantém nítida predilecção), mas os barões assinalados, pois dos reis se ocupou Vasco da Gama [...] (p. 168; grifo do autor).

Mais adiante, Cidade detalha argutamente a composição da narração de Paulo da Gama, relevando não sua função estrutural no poema, mas o objeto de seu discurso (e do poema como um todo) como personagem "cicerone" do Catual:

O narrador [Paulo da Gama], segundo a ficção, confiava pormenores [que ele omite em prol da concisão] à eloquência da pintura, e, em harmonia com uma técnica de sobriedade, passava a outras bandeiras. O Poeta encarregava-o da missão de não omitir nenhum dos episódios mais demonstrativos dos valores individuais de uma história de que seu irmão [Vasco da Gama] dera, a largos traços, a linha evolutiva, na cronológica sucessão dos monarcas. Tudo cumpria tivesse a brevidade do secundário, num poema consagrado à viagem marítima e aos momentos críticos da formação do país que a empreendera. Eram, como já dissemos, altares laterais no templo magnífico, breves anotações, perspectivas fugidias de último plano, no quadro esplêndido" (p. 169).

\footnotetext{
Como Vasco da Gama narrará, a partir do Canto IV, 77ss, sua própria história de partícipe da viagem, deixa de ser apenas homodiegético para atuar também como narrador autodiegético, isto é, aquele que narra sua própria história (SILVA, 2007, p. 761-762).
} 
As qualificações ("a brevidade do secundário"; "breves anotações") e as metáforas exatas ("altares laterais no templo magnífico"; "perspectivas fugidias de último plano, no quadro esplêndido") utilizadas por Hernâni Cidade explicam de certo modo em seu estudo e nos outros a desatenção ao papel estrutural de Paulo da Gama no poema.

No clássico e indispensável “Camões e a estrutura de Os lusíadas”, Jorge de Sena ([1970]1980) evidenciou aspectos fundamentais para se compreenderem a função e o sentido de cada canto, cada episódio, cada discurso que Luís de Camões apresenta em sua epopeia, "um prodígio de arte narrativa" e um "prodígio de arquitectura significativa" (SENA, 1980, p. 67; grifo do autor). A estrutura do poema baseada em duas partes, divididas por sua vez em cinco cantos cada uma, permite-nos avaliar a consequência da arte e do engenho de que se valeu o poeta para formular o "canto aos feitos da famosa gente" (CAMÕES, 2000, p. 1). ${ }^{2}$

Como num espelho, segundo o estudo de Sena, os primeiros cantos se refletem nos cinco últimos, de modo que no Canto I e VI aparece a narração da viagem, na costa oriental da África, entremeada pelo concílio dos deuses aéreos (no I) e marinhos (no VI); no Canto II e VII duas cidades acolhem os portugueses, Melinde (no II) e Calicute (no VII); no Canto III e VIII, Vasco da Gama assume a narração dos feitos dos reis portugueses (no III), e Paulo da Gama expõe (no VIII) as bandeiras e os heróis lusitanos; no Canto IV e IX, a saída da armada em julho de 1497, de Lisboa em direção a Calicute, sob a severa crítica do "velho, d’aspeito venerando" (no IV) e a saída das naus portuguesas em agosto de 1498, de Calicute em direção a Lisboa, sob os auspícios da Ilha dos Amores, o prêmio aos portugueses (no IX); no Canto V e X, as profecias nefastas de Adamastor (no V) e as profecias positivas de Tétis sobre as lutas e as vitórias lusas (no $\mathrm{X}$ ), cantos em que se dá o contato "maravilhoso" entre os portugueses e os mitos, fundindo-se excepcionalmente os dois planos da narrativa camoniana: o histórico (Vasco e os navegantes) e o mítico (Adamastor e Tétis e suas ninfas). Esses paralelos estruturais podem ser mais claramente percebidos no quadro a seguir.

\begin{tabular}{|l|l|}
\hline CANTO I $^{3}$ & CANTO VI \\
\hline Narrador $_{1}$ (narração e excursos) & Narrador $_{1}$ \\
\hline Narração da viagem (costa oriental da África) & Narração da viagem (Costa oriental da África) \\
\hline Concílio olímpico (Júpiter preside) & Concílio marinho (Netuno preside) \\
\hline Baco e Vênus em disputa & Baco e Vênus em disputa \\
\hline
\end{tabular}

\footnotetext{
Nas referências, indicamos algumas edições de que nos valemos simultaneamente para a produção deste trabalho. Optamos, no entanto, pela edição do Instituto Camões, com prefácio de Álvaro Júlio da Costa Pimpão e apresentação de Aníbal Pinto de Castro (2000), por estar disponível eletronicamente, o que facilita e garante a transcrição fiel do poema. Nas próximas citações, indicaremos apenas o canto, em algarismo romano, e a estrofe, em arábico.

3 Cf. o quadro mais detalhado de Emanuel Paulo Ramos ([s. d.], p. 42).
} 


\begin{tabular}{|l|l|}
\hline CANTO II & CANTO VII \\
\hline Narrador $_{1}$ & Narrador \\
\hline Narração da viagem (costa oriental da África) & Narração da viagem (costa oriental da África) \\
\hline Armadilhas de Baco e proteção de Vênus & Armadilhas de Baco e proteção de Vênus \\
\hline Chegada a Melinde & Chegada a Calicute \\
\hline
\end{tabular}

\begin{tabular}{|l|l|}
\hline CANTO III & CANTO VIII \\
\hline Narrador $_{2}$ (Vasco da Gama) & Narrador $_{3}$ (Paulo da Gama) \\
\hline Narração da História de Portugal (reis) & Narração da História de Portugal (vassalos) \\
\hline Lugar da narração: Melinde & Lugar da narração: Calicute \\
\hline
\end{tabular}

\begin{tabular}{|l|l|}
\hline CANTO IV & CANTO IX \\
\hline Narrador ${ }_{2}$ (Vasco da Gama) & Narrador $_{1}$ \\
\hline Saída das naus de Lisboa em direção a Calicute & Saída das naus de Calicute em direção a Lisboa \\
\hline $\begin{array}{l}\text { Episódio do Velho do Restelo } \\
\text { (crítica ao empreendimento marítimo) }\end{array}$ & $\begin{array}{l}\text { Episódio da Ilha dos Amores } \\
\text { (prêmio ao empreendimento marítimo) }\end{array}$ \\
\hline
\end{tabular}

\begin{tabular}{|l|l|}
\hline CANTO V & CANTO X \\
\hline Narrador $_{2}$ (Vasco da Gama) e Narrador & \\
\hline $\begin{array}{l}\text { Viagem em direção a Calicute } \\
\text { e passagem por Melinde }\end{array}$ & $\begin{array}{l}\text { Narrador }_{1} \text {, narração prospectiva } \\
\text { da Ninfa e de Tétis }\end{array}$ \\
\hline $\begin{array}{l}\text { Episódio do gigante Adamastor } \\
\text { (os perigos do empreendimento marítimo) }\end{array}$ & $\begin{array}{l}\text { Viagem em direção a Lisboa } \\
\text { e passagem pela Ilha dos Amores }\end{array}$ \\
\hline
\end{tabular}

Apesar de ter notado tudo isso - o que, seguramente, não é pouco -, Sena parece não ter tido tempo para analisar mais detidamente a função de Paulo da Gama na "arquitetura significativa" do poema.

Dada a dificuldade de examinar toda a fortuna crítica acerca do poema e, pontualmente, sobre o que interessa comentar, isto é, a importância estrutural da narração de Paulo da Gama, verificamos os verbetes do recente Dicionário de Luís de Camões, coordenado por um dos mais argutos investigadores da obra desse poeta, Vítor de Aguiar e Silva (2011), que reuniu especialistas e seus estudos mais atuais e autorizados. Dentre os diversos verbetes sobre camonistas, mitos, cancioneiros, recepção de Camões em várias literaturas, contemporâneos, contexto histórico e cultural etc., curiosamente, não se abre um item dedicado a Paulo da Gama, no entanto mencionado passim nos outros verbetes sobre a epopeia. São sete as referências a esse personagem camoniano. A mais alentada se encontra no verbete "Baco", em que Aguiar e Silva descreve, a propósito da narração de Paulo, seu discurso como "ecfrástico [...]" (2011, p. 63), uma vez que é baseado na descrição das pinturas impressas nas bandeiras da nau. As outras referências se atêm a sua função de narrador "das bandeiras", sem maiores detalhes. 
No Estudos sobre o vocabulário de Os Lusíadas, de Jorge de Sena (1982), o nome do irmão de Vasco da Gama aparece igualmente em sete referências a sua narração sobre as bandeiras, mas sem uma observação que realce sua função de narrador à altura de Vasco, exceto talvez na p. 415 (no item incompleto "XIV: Deus e os deuses" [p. 409-418]), em que o ensaísta, comentando o teor das "falas de Camões"4 e de seus personagens ao longo do poema, parece considerar a importância da participação narrativa de Paulo, mas de todo modo secundária (ou mesmo eventual), já que não paralela à do narrador épico nem à de Vasco da Gama: "Outras personagens tem longas falas: Paulo da Gama, ao descrever as bandeiras no Canto VIII, e a Ninfa e a deusa Téthys quando profetizam na Ilha dos Amores (Canto X), por exemplo". ${ }^{5}$ A propósito do vocabulário de Os Lusíadas ainda, mencione-se uma obra afim do século XVII: na Micrologia camoniana, publicada em 1672, João Franco Barreto expõe um verbete de três linhas sobre Paulo da Gama, restringindo-se a sua biografia mínima: "Era irmão de Vasco da Gama, descubridor da Índia, em cuja jornada o acompanhou; e à volta morreo e foy enterrado na Ilha 3a no Mosteiro de S. Francisco" (1982, p. 606).

Para discutir essa posição dos críticos, ${ }^{6}$ voltemos ao poema, Canto I, 1-2, ou seja, à sua proposição. Sabemos que Camões pretendeu cantar, espalhando por todo o mundo, se o ajudassem engenho e arte, as "armas e os barões assinalados" que partiram de Lisboa em direção ainda além da Taprobana. Uma oitava inteira, portanto, é dedicada ao louvor ("cantando") não de todos os varões e de suas armas, mas especificamente ao daqueles que navegaram com Vasco da Gama em direção à Índia. Previsivelmente, portanto, o canto pretende destacar não as vitórias portuguesas desde suas primeiras batalhas no século XII, mas as viagens quatrocentistas que estabeleceram, como se sabe, a via marítima para o Oriente e garantiram a edificação do império ultramarino.

Posto em relevo o principal objeto de canto épico de Os Lusíadas na primeira estrofe, ouverture da epopeia, Camões abre a segunda estrofe e, em vez de apenas ampliar o elogio das ações dos navegadores e fechar a proposição e, em seguida, invocar a Musa ou, antes, encarecer o poema - considerando-se que a terceira estrofe visa encarecer a perspectiva histórica e não mítica ou lendária de sua narrativa, traço comum nas epopeias que lhe serviram de modelo imitativo -, ele expande a proposição, usando uma conjunção aditiva e um advérbio inclusivo ("E também [...]") para destacar, mas em segundo plano - o primeiro é o dos navegadores -, as "memórias dos reis", e, em terceiro plano, aqueles que por obras valiosas se libertaram da lei da morte:

\footnotetext{
4 Afirma Sena: "Embora, evidentemente, todo o poema represente ou pretenda representar o que Camões pensa, nem sempre nele é ele quem pessoalmente fala. Várias personagens têm no poema a palavra; e Vasco da Gama, para contar ao Rei de Melinde a história de Portugal até a sua partida de Lisboa, e a sua viagem até Melinde, é quem fala ao longo de três cantos (III, IV, V)" (1982, p. 415; grifo do autor).

5 A título de curiosidade, no Índice analítico do vocabulário de Os Lusíadas, Antônio Geraldo da Cunha registra quatro menções a Paulo da Gama (uma quinta referência seria ao apóstolo Paulo [1980, p. 159]). Para Vasco, há três (p. 219). Quanto a Gama, 48 ocorrem, das quais sete dizem respeito a Paulo (p. 95).

6 Nas anotações e comentários às edições de Os Lusíadas, essa posição é aliás mantida. Vejam-se, por exemplo, os de Emanuel Paulo Ramos (CAMÕES, [s. d.], 462-491), Álvaro Júlio da Costa Pimpão (CAMÕES, 2000, p. 322-386), Carlos Eduardo Falcão Uchoa, sobre o Canto VII, e os de Lia Corrêa Dutra, sobre o VIII (CAMÕES, [1972] 1999, p. 425-470; p. 471-522).
} 
As armas e os Barões assinalados

Que da Ocidental praia Lusitana

Por mares nunca de antes navegados

Passaram ainda além da Taprobana,

Em perigos e guerras esforçados

Mais do que prometia a força humana,

E entre gente remota edificaram

Novo Reino, que tanto sublimaram;

E também as memórias gloriosas

Daqueles Reis que foram dilatando

A Fé, o Império, e as terras viciosas

De África e de Ásia andaram devastando,

E aqueles que por obras valerosas

Se vão da lei da Morte libertando,

Cantando espalharei por toda parte,

Se a tanto me ajudar o engenho e arte (I, 1-2).

A hierarquia em planos ("barões" marinheiros, "reis", "aqueles") não significa, no entanto, desvalorização, uma vez que os reis não estariam evidentemente, na sequência da proposição, em segundo lugar, antecipando-lhes os marinheiros e sucedendo-lhes os "vassalos". Implica, isto sim, uma ordem que só a "arquitetura significativa” do poema explica e sustenta, como ponderou sensivelmente Jorge de Sena, e que passamos a analisar.

Como se observa no quadro apresentado das correspondências dos cantos, segundo Sena, duas cidades acolhem os portugueses na costa índica, permitindo-lhes o descanso e a oportunidade de se fazerem conhecer por meio de narrativas que explicarão a fama dos portugueses (Canto II, estrofe 72ss) e das bandeiras pintadas na nau lusitana (Canto VII, estrofe 1ss). No primeiro caso, o rei de Melinde (no II), inspirado por Mercúrio que sopra aos melindanos a fama da gente ilustre, pede a Vasco da Gama que lhe exponha as aventuras dos "barões assinalados", figurando-se aí as "memórias gloriosas / Daqueles reis" (III e IV).

- «Mas antes, valeroso Capitão,

Nos conta (lhe dizia), diligente,

Da terra tua o clima e região

Do mundo onde morais, distintamente;

E assi de vossa antiga geração,

E o princípio do Reino tão potente,

Cos sucessos das guerras do começo,

Que, sem sabê-las, sei que são de preço;

[...] 
«E não menos co tempo se parece

O desejo de ouvir-te o que contares;

Que quem há que por fama não conhece

As obras Portuguesas singulares?

Não tanto desviado resplandece

De nós o claro Sol, pera julgares

Que os Melindanos têm tão rudo peito

Que não estimem muito um grande feito (II, 109;111).

No segundo caso, em Calicute (no VII), o Catual "Pelo que vê pergunta" (VII, 75), a que Paulo da Gama se prontifica a responder, narrando a história desenhada na seda das bandeiras. ${ }^{7}$ O narrador épico, antes de passar a palavra para Paulo, expõe a circunstância do encontro:

Já com desejos o Idolatra ardia

De ver isto que o Mouro lhe contava;

Manda esquipar batéis, que ir ver queria

Os lenhos em que o Gama navegava.

Ambos partem da praia, a quem seguia

A Naira geração, que o mar coalhava;

À capitaina sobem, forte e bela,

Onde Paulo os recebe a bordo dela.

Purpúreos são os toldos, e as bandeiras

Do rico fio são que o bicho gera;

Nelas estão pintadas as guerreiras

Obras que o forte braço já fizera;

Batalhas têm campais aventureiras,

Desafios cruéis, pintura fera,

Que, tanto que ao Gentio se apresenta,

A tento nela os olhos apacenta.

Pelo que vê pergunta; mas o Gama

Lhe pedia primeiro que se assente

E que aquele deleite que tanto ama

A seita Epicureia experimente.

Dos espumantes vasos se derrama

Como anota Álvaro Júlio da Costa Pimpão, "A visita do Catual às naus é ficção poética e prepara a descrição das bandeiras do canto seguinte; 'Manda esquipar batéis, ...: manda preparar e guarnecer com tripulantes; 'Ambos partem ...; o Catual e Monçaide; 'A Naira geração, que o mar coalhava': Vasco da Gama estava em terra. Esta saída de Vasco da Gama não se verificou sem ordens rigorosas a quem ficava a substituí-lo, seu irmão Paulo da Gama: '\& que ficasse na frota por capitão mór seu irmão, \& que durando sua ausencia não recolhesse nela pessoa algũa, \& todos os que fossem a bordo estevessem ẽ suas almadias' (Castanheda, I.XVI). Toda esta cena é, pois, imaginada pelo Poeta" (CAMÕES, 2000, p. 338). 
O licor que Noé mostrara à gente;

Mas comer o Gentio não pretende,

Que a seita que seguia lho defende.

A trombeta, que, em paz, no pensamento

Imagem faz de guerra, rompe os ares;

Co fogo o diabólico instrumento

Se faz ouvir no fundo lá dos mares.

Tudo o Gentio nota; mas o intento

Mostrava sempre ter nos singulares

Feitos dos homens que, em retrato breve,

A muda poesia ali descreve.

Alça-se em pé, co ele o Gama junto,

Coelho de outra parte e o Mauritano;

Os olhos põe no bélico trasunto

De um velho branco, aspeito venerando,

Cujo nome não pode ser defunto

Enquanto houver no mundo trato humano:

No trajo a Grega usança está perfeita;

Um ramo, por insígnia, na direita (VII, 73-77).

Os versos apresentam não apenas a curiosidade do Catual (“Já com desejos o Idolatra ardia / De ver isto que o Mouro lhe contava"), a visita ansiada ("À capitaina sobem, forte e bela"), a etiqueta hospitaleira do cicerone Paulo da Gama que acomoda o estrangeiro (“[...] o Gama / Lhe pedia primeiro que se assente / E que aquele deleite [o licor] que tanto ama / A seita Epicureia experimente"), mas antecipam o que será descrito e narrado seguidamente não mais pelo narrador épico, mas por Paulo da Gama, no Canto VIII: as pinturas ("Purpúreos são os toldos, e as bandeiras / Do rico fio são que o bicho gera"), as batalhas ("Nelas estão pintadas as guerreiras / Obras que o forte braço já fizera") e seus heróis-vassalos ("Feitos dos homens que, em retrato breve, / A muda poesia ali descreve ${ }^{8 ”}$ ) e seus retratos breves ("Os olhos põe no bélico trasunto") de personagens secundários (CIDADE, 1968, p. 168), porque figuram sobretudo os antecessores dos atuais heróis, os navegadores do final do século XV.

C Cf. a propósito da "feição eminentemente visualista, epidíctica e demonstrativa, apoiada na presença física, real ou imaginária, do objeto que elas [as descrições] pretendem descrever, segundo o conhecido processo da ekphrasis", aspecto que escapa ao propósito pontual deste estudo, o artigo de Sebastião Tavares de Pinho (2003, p. 185) e, anterior, o ensaio de António José Saraiva, "Ut pictura poesis", em que ele afirma que "[...] Camões escolheu as bandeiras pintadas ou as tapeçarias para apresentar diversas acções da história de Portugal no canto VIII. É uma escolha adequada à sua própria visão dessas acções, repito, uma visão pictural" (1996, p. 83). 


\title{
A vez e a "voz discreta" de Paulo da Gama
}

Assim, nessa segunda solicitação de narração por parte de um estrangeiro interessado no prestígio português, não é o narrador épico (ou o Narrador ${ }_{1}$, segundo Berardinelli), nem Vasco nem Nicolau Coelho, mas Paulo da Gama que lhe conta a gesta daqueles "que por obras valerosas / Se vão da lei da morte libertando" (I, 2). Vejamos a passagem da narração do narrador épico ${ }^{9}$ para Paulo, "cuja voz discreta" é interpretada pelo mauritano Monçaide. Antes, detenhamo-nos no adjetivo "discreta", qualificador da voz narrativa.

No minucioso Índice analítico do vocabulário de Os Lusíadas, Antonio Geraldo da Cunha (1980, p. 63) registra cinco ocorrências do adjetivo: uma na 50a estrofe do Canto I ("As discretas repostas que conuinhão"), outra na 49a do VI ("Que por cartas discretas \& polidas") e as três outras no Canto VIII, em que ocorre a narração de Paulo: "Paulo responde, cuja voz discreta" (1 ${ }^{\text {a }}$ estrofe), "E com razões notáueis \& discretas" (53ª) e "Nestas palavras o discreto [Vasco da] Gama" (86a). Hamilton Elia, que comenta o Canto I, em que ocorre pela primeira vez o termo, e Maria Amélia Pontes Vieira, que comenta o Canto VI, nada registram acerca da palavra. Lia Corrêa Dutra, por sua vez, anotando o Canto VIII (CAMÕES, 1972, p. 427-476), destaca "discretas" apenas na nota à estrofe 53, atribuindo-lhe o sentido de "cautelosas, prudentes" (p. 453), o que coincide com a acepção corrente de comedido, reservado, modesto, circunspecto (HOUAISS; VILLAR, 2001, p. 1.053) e parece indicar que o adjetivo não tinha um sentido específico no século XVI.

Isso posto, voltemos à passagem da narração para o discreto Paulo da Gama:

Na primeira figura se detinha

O Catual que vira estar pintada,

Que por divisa um ramo na mão tinha,

A barba branca, longa e penteada.

Quem era e por que causa lhe convinha

A divisa que tem na mão tomada?

Paulo responde, cuja voz discreta

O Mauritano sábio lhe interpreta:

$\overline{9}$ Recorde-se que na altura da estrofe 78 do Canto VII, o narrador épico interrompe sua narrativa (VII, 78,1) para realizar, em primeira pessoa, um excurso sobre o valor daqueles "que aventuraram / Por seu Deus, por seu rei, a amada vida" (VII, 87), inclusive o próprio poeta, que a "A Fortuna me traz peregrinando" (VII, 79,3), concluindo em seguida esse Canto:

\author{
Um ramo na mão tinha... Mas, ó cego, \\ Eu, que cometo, insano e temerário, \\ Sem vós, Ninfas do Tejo e do Mondego, \\ Por caminho tão árduo, longo e vário! \\ Vosso favor invoco, que navego \\ Por alto mar, com vento tão contrário \\ Que, se não me ajudais, hei grande medo \\ Que o meu fraco batel se alague cedo (VII, 78).
}


- «Estas figuras todas que aparecem,

Bravos em vista e feros nos aspeitos,

Mais bravos e mais feros se conhecem,

Pela fama, nas obras e nos feitos.

Antigos são, mas inda resplandecem

Co nome, entre os engenhos mais perfeitos.

Este que vês, é Luso, donde a Fama

O nosso Reino «Lusitânia» chama (VIII, 1-2).

Esses dados iniciais nos colocam diante da seguinte questão: que "eventualidade" existiria no fato de Camões ter escolhido, entre seus personagens, os irmãos Vasco e Paulo da Gama para a narração da história portuguesa passada, causadora de curiosidade tanto no rei de Melinde como no Catual - especialmente se considerarmos que ficará por conta dos mitos (Júpiter, Adamastor, Ninfa e Téthys) a narração da história futura da gente lusitana (e eventualmente, sim, Veloso narrará aos marinheiros, para entretenimento - e não necessariamente para informação -, um episódio cavalheiresco, conhecido como os “Doze de Inglaterra”)?

Para Cleonice Berardinelli - e para camonistas anteriores e posteriores -, dois narradores são elaborados por Camões para o desenvolvimento de sua narrativa: o Narrador ${ }_{1}$ e o Narrador $_{2}$, ficando os outros, como vimos, na categoria de eventuais. Quer nos parecer, contudo, que Camões pretendesse apoiar sua Musa (ou Ninfas) nova(s) em três, equiparando-os por meio de pistas estruturais como a da proposição e a do paralelo observado por Sena entre as duas partes do poema.

Em relação ao primeiro item, em que se apoia o argumento com que pretendemos defender a não eventualidade do papel narrativo de Paulo da Gama, a proposição, não são dois mas três instâncias de rememoração e de canto que esta expõe claramente: os feitos dos navegantes, os feitos daqueles reis e os feitos dos ("aqueles") "valerosos", como vimos preliminarmente. No que concerne aos demonstrativos, poderíamos supor que as "obras valerosas" se refeririam sinteticamente ao que fizeram apenas os barões e os reis, mas Camões distingue os agentes desses feitos por meio dos pronomes na segunda estrofe: "daqueles Reis" e "aqueles que por obras valerosas", assegurando nossa leitura de que há três nítidos objetos de louvor e memória no poema.

Como Os Lusíadas é uma epopeia marinheira, Camões dispõe de um narrador heterodiegético interventivo para contar a viagem de Vasco e de sua armada de Lisboa a Calicute e desta cidade a Lisboa. Em mise-en-abyme - a garantir a imitatio dos modelos épicos de Homero e de Virgílio -, Camões faz com que aquele narrador interrompa a narrativa da viagem para contar, por meio de Vasco da Gama e de Paulo da Gama, os episódios passados que levaram os portugueses à situação odepórica em que se achavam (como Ulisses narra aos feáceos, na Odisseia homérica, as causas de seu vaguear em direção a Ítaca, após a guerra de Troia, por exemplo). 
Um parêntese necessário a propósito da classificação "heterodiegético interventivo" na epopeia: embora compreendamos o argumento dos críticos, em especial os de Berardinelli e de Sena, no que concerne à diferenciação no enunciado narrativo de Os Lusíadas de duas vozes distintas, a do Narrador (terceira pessoa) e a do Poeta (primeira), parece-nos mais adequado considerar o narrador principal como heterodiegético interventivo, cuja expressão subjetiva perpassa todo o poema (o que Cleonice Berardinelli designa de "excursos"), na medida em que se considere que

as funções do narrador não se esgotam no ato da enunciação que lhe é atribuído. Como protagonista da narração ele é detentor de uma voz observável ao nível do enunciado por meio de intrusões, vestígios mais ou menos discretos da sua subjetividade, que articulam uma ideologia ou uma simples apreciação particular sobre os eventos relatados e as personagens referidas (REIS; LOPES, 1988, p. 63).

Nessa linha de pensamento, e em que pese tratar-se o narrador de um poeta épico, ou seja, um cantor (modernamente relacionado à modalidade e aos gêneros líricos), o que importa na epopeia é a narração objetiva dos feitos de um herói. Necessariamente, portanto, o narrador não participará das ações do poema, haja vista sua distância no tempo, seja este mítico (como nas epopeias antigas) ou histórico (como se pretende em Os Lusíadas). Sendo heterodiegético, nada impede que esse narrador exponha em primeira pessoa os itens metalinguísticos da épica (proposição e invocação) e as opiniões e reflexões, isto é, os excursos acerca do que narra. Dividir as vozes narrativas atribuindo-as ora ao Narrador ora ao Poeta ${ }^{10}$ parece rasurar uma marca importante da narração épica: a criação de um narrador que expõe a história e, ao mesmo tempo, reflete sobre ela, sem fazer parte dessa história ${ }^{11}$ do final do século XV, protagonizada por Vasco da Gama, Paulo da Gama e Nicolau Coelho.

Assim sendo, Camões cria um narrador épico heterodiegético interventivo que, como autor textual, desenvolve sua narrativa principalmente histórica ${ }^{12}$ - eis o diferencial, vale lembrar, encarecido nas estrofes 3 e 11 do Canto I,

10 Cumpre notar que esta subdivisão da voz do Narrador e do Poeta, como duas instâncias separadas, é ausente da discussão acerca da poesia épica da qual Camões é devedor. Se, sem dúvida, em muitas instâncias é possível falar de diferentes vozes ou pontos de vista, a análise se dá sempre quanto ao texto, seja como na análise de Fowler (1999), em que, em paralelo ao narrador, surge a figura do focalizador; seja na observação de ambiguidades na própria voz do narrador, que pode revelar uma polifonia por vezes despercebida, como em Behr (2005). Em ambos os casos, no entanto, os comentadores se escusam de discutir o Poeta como uma invasão da realidade empírica sobre a narrativa, talvez porque, naqueles casos, os muitos séculos que se interpõem entre poeta e comentador afastam este de buscar entender aquele.

11 Vale lembrar, com Aguiar e Silva, que o "narrador é classificado como heterodiegético, se não é correferencial com nenhuma das personagens da diegese, se não participa, por conseguinte, na história narrada. [...] O narrador heterodiegético pode manifestar-se como um 'eu' explícito ou como um narrador apagado, de 'grau zero', fundido com o autor textual' (2007, p. 761).

12 Embora seja comum o uso desse adjetivo na crítica camoniana, embasada na enfática proposta historicista de Camões a reclamar para seu poema uma narrativa que se distinga daquelas que contam "vãs façanhas, / Fantásticas, fingidas, mentirosas" (I, 11), António José Saraiva, em "Função e significado do maravilhoso n’Os Lusíadas", lembra-nos o fato de que, "Do ponto de vista literário, estético, Os Lusíadas não são uma narrativa histórica. A história dos Portugueses, anunciada como tema nas primeiras estrofes do Poema, é contada dispersa e fragmentariamente por várias personagens, umas humanas, quando se trata de factos passados (que cabem na memória dos homens), outras divinas, quando se trata de acontecimentos futuros, que os homens ainda não conhecem, mas que os deuses, por serem intemporais, têm presentes como se os estivessem olhando" (1996, p. 117). 
Cessem do sábio Grego e do Troiano

As navegações grandes que fizeram;

Cale-se de Alexandro e de Trajano

A fama das vitórias que tiveram;

Que eu canto o peito ilustre Lusitano,

A quem Neptuno e Marte obedeceram.

Cesse tudo o que a Musa antiga canta,

Que outro valor mais alto se alevanta (I, 3).

Ouvi, que não vereis com vãs façanhas,

Fantásticas, fingidas, mentirosas,

Louvar os vossos, como nas estranhas

Musas, de engrandecer-se desejosas:

As verdadeiras vossas são tamanhas

Que excedem as sonhadas, fabulosas,

Que excedem Rodamonte e o vão Rugeiro

E Orlando, inda que fora verdadeiro.

Por estes vos darei um Nuno fero,

Que fez ao Rei e ao Reino tal serviço,

Um Egas e um Dom Fuas, que de Homero

A cítara par' eles só cobiço;

Pois polos Doze Pares dar-vos quero

Os Doze de Inglaterra e o seu Magriço;

Dou-vos também aquele ilustre Gama,

Que para si de Eneias toma a fama (I, 11-12),

mas mantendo-se as leis básicas do gênero épico: a natureza lendária (o aparecimento de Cristo a Afonso Henriques, por exemplo [III, 45]) e mítica da narrativa (Júpiter a garantir a decisão dos Fados de favorecerem os lusitanos [I, 24], Marte e Vênus a endossarem-na [I, 33, 36-38], Baco [I, 30-32] e Netuno [VI, 35] a rejeitarem-na; a raiz genealógica dos lusitanos entroncada em Luso, companheiro de Baco [VII, 77; VIII, 1-4]), além da proposição, da invocação e da narração in medias res.

Isso considerado, arma Camões sua epopeia em três vozes narrativas fundamentais, de modo a garantir que aquelas três instâncias da proposição sejam concretizadas: cabe ao poeta narrador heterodiegético interventivo contar a história da viagem (saída de Lisboa, 8 de julho de 1497; chegada a Calicute, 17 de maio de 1498; chegada a Lisboa, 12 de julho de 1499) e da peleja entre as alegorias do Oriente (Baco, parte negativa da viagem) e do Ocidente (Vênus, parte propícia do percurso marítimo). Para efeito de valorização da narrativa em mise-en-abyme dos reis e dos "valerosos", Camões lança mão de um capitão, Vasco da Gama, equivalente, na armada, ao próprio 
rei Dom Manuel, que o encarregou de realizar a viagem em seu nome, e de seu "vassalo", Paulo da Gama, equivalentes aos homens que ajudaram ao(s) rei(s) em sua conquista.

Nesse ponto de vista, e em outros termos, se ao poeta heterodiegético inspirado pelas Tágides/Musa cabe narrar toda a história, caberá a um grande do reino narrar a história (a memória) dos reis de Portugal e a um vassalo, a dos heróis que os ajudaram. Cada um terá uma função significativa e proporcional na narrativa: a oitava integral dedicada à proposição referente aos navegadores equivaleria ao teor do poema como um todo: narração da viagem heroica; os quatro versos da segunda oitava equivaleriam aos três cantos (III, IV e V) dedicados à história gloriosa dos reis, cujo efeito e consequência principais seriam o do investimento ousado nas navegações e a edificação do império; e os dois versos seguintes (5 e 6) equivaleriam à parte do Canto VII e do início do VIII, em que Paulo da Gama descreve a pintura das vitórias dos heróis "menores".

Decerto, o fato de Paulo da Gama narrar em apenas um canto o significado das pinturas expostas nas bandeiras pode ter levado Berardinelli e outros críticos a considerarem-no eventual na sequência narrativa do poema, se ponderarmos o peso do "Narrador " e de Vasco da Gama, como o Narrador ${ }_{2}$. No entanto, em termos de estrutura tripartida da proposição e sua projeção em três narradores, sendo dois deles, os irmãos Gama, os principais na história da viagem, não pode ser pequena nem eventual essa escolha de Paulo como narrador no Canto VII/VIII.

Em cotejo com o episódio dos melindanos, cujo rei interpela diretamente Vasco da Gama a narrar os feitos da gente ilustre, os hindus são representados pelo Catual, que pergunta a Paulo sobre as figuras eminentes, como vimos. É curioso como Camões trata proporcionalmente a narração da história passada antes das navegações: o interpelador de Vasco é o próprio rei de Melinde, na medida em que o português é o arauto de Dom Manuel e em seu nome viaja; solene, a narração do capitão se estende por três cantos. No Canto VII/VIII, não o rei (Samorim de Calicute) mas seu funcionário interpela um português, não o representante direto do rei, mas seu vassalo, Paulo da Gama, que narra solene, mas não extensamente os episódios “valerosos".

Considerando a engenhosidade de Camões na composição do poema e a argúcia de Jorge de Sena na análise de sua "arquitetura significativa", a escolha de Paulo da Gama como narrador das bandeiras talvez esteja amparada em dados históricos que sua narrativa, por respeito à lei da brevidade poética, acaba por deixar pressupostos, já que conhecidos dos receptores da época. Assim sendo, vale expor alguns dados hoje talvez pouco conhecidos de sua trajetória, segundo crônicas da época.

Ainda que "vassalo", Paulo da Gama era fidalgo de não pouco prestígio ao tempo da viagem e depois. Segundo a crônica de Fernão Lopes de Castanheda, História do descobrimento \& conquista da Índia pelos portugueses, a posição ocupada por Vasco teria sido oferecida primeiro a Paulo (CASTANHEDA, [1552] 1833, I.II.1), mas este teria declinado em função de sua saúde instável, que, como é sabido, causará sua morte no retorno a Lisboa: 
E estes tres nauios auia de mandar a este descobrimẽto \& cõ a capitania mór deles cometeo hũ Paulo da gama caualeyro de sua casa filho q fora Desteuão da gama alcayde mór da vila de Sinis no campo douriq, em q tinha grande confiança por ele ser pera isso. Do q se ele escusou por hũa doença que tinha com q não poderia sofrer os trabalhos de capitão mór, pedindo a el rey q fizesse merce daqle cargo a hũ seu irmão mais moço chamado Vasco da gama q ho saberia muy bẽ seruir, \& q ele iria tambẽ na armada por capitão pera o acõselhar \& ajudar. Do q el Rey foy contente por saber q era assi, \& que era Vasco da gama espremẽtado nas cousas do mar em q tinha feyto muyto seruiço a el Rey dom João: \& q era homẽ de grandes spiritos: \& muyto proprio pera dar fim a este descobrimẽto [...] (CASTANHEDA, [1552] 1833, p. $\left.6^{13}\right)$.

No manuscrito anônimo conhecido como Roteiro da viagem de Vasco da Gama (AMES, 2009), Paulo é personagem de ação e ocupa lugar relevante na narrativa. Também Castanheda é prolífico em relatar passagens em que a sabedoria, a liderança e a boa vontade de Paulo da Gama ocupam lugar de destaque, como no primeiro episódio de escorbuto (CASTANHEDA, [1552] 1833, I.IV.16), em que Paulo faz o possível para o conforto dos doentes, inclusive oferecendo remédios de seu uso pessoal.

\& neste tempo passarão os nossos assaz de trabalho com hũa doença que lhes sobreueo, (parece que do ár daquela região) que a muytos lhes inchauão as mãos, \& as pernas \& os pees. E coisto lhes crecião tãto as gengiuas sobre os dentes que não podião comer \& apodreciãlhe, de maneyra que não auia quem soportasse ho fedor da boca, \& coestes males padecião dores muy grãdes, \& morrerã algũs: o que pos a gente em grãde desmayo. E em muyto mayor a posera se não fora por Paulo da gama q era de tão boa condição que de noyte \& de dia visitaua todos, \& os consolaua \& curaua, \& repartia coeles muy largamente dessas cousas de doentes que leuaua pera sua pessoa (CASTANHEDA, [1552] 1833, p. 16-17).

Na obra de Giovanni Pietro Maffei, ${ }^{14}$ publicada em 1588, intitulada Historiarum Indicarum Libri XVI, cujo primeiro livro narra a viagem de Vasco da Gama, o autor apresenta Paulo da Gama

\footnotetext{
13 Para efeito de transcrição de trechos da crônica de Castanheda, optamos pela edição Rollandiana, de 1833.

14 Nascido em Bergamo, em 1536, Maffei foi professor de retórica e eloquência antes e depois de vestir o hábito da Companhia de Jesus. Ainda noviço publicou, em 1570, sua tradução para o latim da História das Missões dos Jesuitas no Oriente, do português Manuel da Costa. Esta obra fez com que fosse convidado a Portugal pelo Cardeal Dom Henrique, mais tarde Henrique I, com a encomenda da escrita de uma História da Conquista da Î́ndia feita pelos portugueses e do sucesso da religião cristã. Maffei passou cinco anos entre Lisboa e Coimbra, recolhendo material sobre a talassocracia portuguesa no Oriente. A morte de seu protetor e a consequente tomada de Portugal pela coroa espanhola fez com que voltasse a Roma, onde prosseguiu com a escrita de sua obra, que seria publicada em 1588 sob o título Historiarum Indicarum Libri XVI e dedicada a Filipe II. A História das Índias de Maffei se insere em um panorama mais amplo do Cinquecento italiano de escritores que escrevem e refletem sobre o cenário do novo mundo para além da Europa, dentre os quais podemos contar Pedro Mártir de Anglería, Girolamo Benzoni, Cesare Federici, Gasparo Balbi, e talvez o mais conhecido, Giovanni Battista Ramusio. Na obra de Maffei, a própria história de Portugal, narrada como uma história de mercadores e viajantes destemidos, encontra-se inextricavelmente conectada com a divulgação da religião cristã, e com sua propagação, tornando a missão evangelizadora e educadora dos jesuítas a verdadeira vocação do reino português, guiado e protegido pela mão divina; a obra põe, como faz Camões, o dilatar da Fé e do Império, num mesmo movimento concertado e orquestrado pelo aeternae mentis numen (nume da providência eterna, primeiras palavras da obra). Maffei é uma testemunha contemporânea da posição que Portugal tinha tanto na política europeia quanto no mundo novo, e da percepção que outros povos tinham desse papel (ANDRETTA, 2004). A pesquisa acerca da obra de Maffei vem sendo realizada pela profa. Dra. Leni Ribeiro Leite com apoio da Fundação de Amparo à Pesquisa do Espírito Santo (Fapes).
} 
primeiro, e Vasco como seu irmão, invertendo, pois, a ordem de apresentação e importância dada por Camões no poema:

Já antes cortada e reunida a madeira; [o rei] ordena que sejam construídas então quatro naus, ágeis para explorar e firmes para resistir; que sejam equipadas com soldados escolhidos, marinheiros, mantimentos e canhões; e, o quanto possa prover o engenho humano, que sejam da melhor e mais zelosa maneira possível preparadas contra todo imprevisto. Foi dado à nau capitânea um nome a partir de São Gabriel, não sem motivo: para que aquela que da nossa terra aos antípodas assegurava o caminho ao Evangelho se depositasse sob tutela e guarda deste arcanjo importantíssimo, que foi o primeiro a um dia trazer o Evangelho do céu à terra. O curso desta nau regia Pero d'Alenquer, que estivera pouco antes abrindo o Cabo da Boa Esperança. Consagrou-se a segunda nau ao Arcanjo Rafael, guia e tutor dos viajantes. Paulo Gama a liderava, e tinha como timoneiro João de Coimbra. A terceira, que tinha Nicolau Coelho como capitão e Pedro Escolástico como timoneiro, não se sabe por que foi chamada Bérrio. A quarta, sem soldados e sem nome, que levava principalmente mantimentos a mais, era guiada por Gonçalo Nunes, empregado de Gama. No todo, soldados e marinheiros eram não mais que cento e sessenta. Acima de todos eles, foi posto pelo Rei Manuel, com o poder supremo, Vasco da Gama, irmão de Paulo, homem de singular prudência e fé e, o que era principal, de invencível força de ânimo; seu pai, Estêvão, há pouco falecido, já havia sido antes escolhido pelo Rei João para esta mesma função (MAFFEI, 1589, p. 24). ${ }^{15}$

Paulo não é, portanto, uma escolha aleatória ou menor, mas a designação de uma personalidade de destaque para ocupar um papel comparável ao do próprio Vasco.

A corroborar ainda a tese da não eventualidade da função de narrador de Paulo a partir da proposição e do registro de seu prestígio segundo os cronistas, tem-se um aspecto não menos importante: ao iniciar sua narrativa ecfrástica, Paulo da Gama tem sua narração interrompida pelo narrador heterodiegético interventivo - ou do "Poeta", como prefere Berardinelli -, que invoca novamente as Ninfas do Tejo e do Mondego.

Um ramo na mão tinha... Mas, ó cego,

$\mathrm{Eu}$, que cometo, insano e temerário,

Sem vós, Ninfas do Tejo e do Mondego,

\footnotetext{
5 "Caesa et conuecta iam ante materia; naues in praesentia duntaxat quattuor ad explorandum agiles, ad tolerandum firmas, delecto milite, nauta, commeatibus, tormentis instrui: et quantum humano consilio provideri possit, contra omnes casus quam diligentissime optimeque adornari jubet. Praetoriae inditum est nomen a sancto Gabriele, non sine causa: ut quae ex orbe nostro ad antipodas viam Evangelio muniebat; sub tutela praesidioque lateret Archangeli potissimum eius, qui primus e caelo terris olim attulit Euangelium. Huiusce navis cursum regebat Petrus Alanquerius, qui aperiendo Bonae spei promontorio paulo ante interfuerat. Secundam Archangelo Raphaeli, viatorum duci ac tutori, dicarat. Paulus Gamma praeerat, nauclerum habebat Ioannem Conimbricensem. Tertiam Nicolao Coelio nauarcho, Petro Scholastico gubernatore, incertum unde, Berrium appellabant. Quarta, sine milite ac sine nomine, vehendis duntaxat in supplementum cibariis, a Consaluo Nonnio Gammae domestico ducebatur. Propugnatores in universum et nautae centum et sexaginta non amplius explebant numerum. Iis omnibus ab Emmanuele praeficitur summa cum potestate Vascus Gamma Pauli frater, singulari prudentia ac fide, et, quod caput erat, inuicto animi robore vir: cuius patrem Stephanum, nuper vita functum, Ioannes Rex ad munus idipsum iam ante delegerat" (Tradução de Leni Ribeiro Leite).
} 
Por caminho tão árduo, longo e vário!

Vosso favor invoco, que navego

Por alto mar, com vento tão contrário

Que, se não me ajudais, hei grande medo

Que o meu fraco batel se alague cedo (VII, 78).

Assim, o uso da invocação dimensiona a relevância e a solenidade da narração rememorativa (o que não ocorre com as narrativas dos eventuais Adamastor [V, 41-48], Veloso [VI, 41-69], Júpiter [II, 44-55], por exemplo): as Ninfas do Tejo/Tágides são invocadas no início do poema (I, 4-5); Calíope o é no início do extenso flashback de Vasco da Gama (III, 1-2). A retomada das Ninfas no Canto VII não pode ser, portanto, ocasional nem aleatória. Ela acompanha as principais vozes da epopeia camoniana - como a da Ninfa e a de Tétis, na Ilha dos Amores (X, 7-74 [Ninfa]; X, 79-143), dada a magnitude do assunto: a história futura, pós-navegação vascaína.

Vale observar que as narrativas dos mitos (gigante, ninfa e deusa) têm caráter exclusivamente prospectivo, pois são vaticínios ou profecias do que ocorrerá após a viagem de Vasco da Gama; neste sentido, são a história futura no plano cronológico da narrativa (anos de 1490), ainda que já ocorrida no plano temporal da produção da epopeia por Camões (anos de 1560-70). Não devem ser contados como narradores na mesma proporção dos humanos e históricos Vasco e Paulo da Gama, cujas narrativas desvelam naturalmente o passado que os conduziu àquele momento de glória, a via marítima.

\section{O papel de Paulo da Gama na "arquitetura significativa" do poema}

O segundo aspecto em que se apoia o argumento que defende a relevância de Paulo da Gama na estrutura narrativa de Os Lusíadas é o paralelo entre as partes e os cantos, conforme a análise de Jorge de Sena. Retomemos as correspondências mais detidamente: o Canto I e o Canto VI têm seu paralelo conseguido na presença da voz do Narrador ${ }_{1}$; na narração voltada para as ações dos navegantes situados no oceano Índico, na costa oriental da África; no episódio do concílio dos deuses, e na disputa entre Baco e Vênus. O Canto II e o Canto VII apresentam paralelismo na permanência da voz do Narrador ${ }_{1}$, na narração voltada ainda para as ações dos navegantes situados na costa oriental da África, e na chegada, após armadilhas de Baco e proteção de Vênus, às cidades principais do poema, Melinde e Calicute. O Canto III e o Canto VIII desenvolvem paralelos na alteração da voz do narrador; na narração da História de Portugal com os narradores posicionados em Melinde e em Calicute. O Canto IV e o Canto IX formam paralelismo na alteração da voz do narrador e na narração da História de Portugal exposta por narradores posicionados em Melinde e em Calicute. O Canto V e o Canto X, finalmente, desenvolvem paralelos na alteração da voz do narrador, na narração da viagem e na fusão dos planos histórico e mítico ou maravilhoso. 
Retomada a síntese dos paralelos narrativos, percebe-se mais claramente que são correspondentes as funções dos narradores principais: Narrador ${ }_{1}$, Narrador ${ }_{2}$ (Vasco da Gama) e Narrador (Paulo da Gama), em especial nos Cantos III e VIII, em que atuam mais evidentemente Vasco e Paulo:

\begin{tabular}{|l|l|}
\hline CANTO III & CANTO VIII \\
\hline Narrador $_{2}$ (Vasco da Gama) & Narrador $_{3}$ (Paulo da Gama) \\
\hline Narração da História de Portugal (reis) & Narração da História de Portugal (vassalos) \\
\hline Lugar da narração: Melinde & Lugar da narração: Calicute \\
\hline
\end{tabular}

A extensão da narração de Paulo não se compara, de fato - e obedecendo à proporção deduzida na análise dos versos da proposição do poema, como vimos -, à de seu irmão: são 43 estrofes ao todo (VIII, 1-43), ao passo que a de Vasco compreende três cantos inteiros. Justifica a diferença, como vimos, o fato de este representar o cetro de D. Manuel e ser o responsável por expor ao soberano de Melinde os 360 anos da história portuguesa, tendo em vista o desempenho glorioso dos reis, de 1139 (quando Dom Afonso I funda e assume a coroa de Portugal) até 1499, quando se conclui a viagem vascaína, sem considerar os anos futuros narrados no poema, que alcançariam o tempo mesmo de Camões, cerca dos anos de 1560.

Diferentemente dos "barões assinalados" - que, saindo de Lisboa, "passaram ainda além da Taprobana" (I, 1) - e dos "reis" - que dilataram o cristianismo e o império "e as terras / De África e de Ásia andaram devastando" (I, 2), os valorosos da narração ecfrástica de Paulo da Gama abrangem mitos (Luso, Ulisses), lendas (Viriato, Sertório), rei (Afonso Henriques), mas, sobretudo, os vassalos portugueses. É justamente isso que diferenciará seu discurso. Nas estrofes iniciais, antes de mencionar o Conde Dom Henrique e, novamente, Afonso Henriques (III 2884), rei fundador e testemunha do aparecimento de Cristo em Ourique, o narrador mostra nas pinturas o retrato de Luso, Ulisses, Viriato e Sertório:

Na primeira figura se detinha

O Catual que vira estar pintada,

Que por divisa um ramo na mão tinha,

A barba branca, longa e penteada.

Quem era e por que causa lhe convinha

A divisa que tem na mão tomada?

Paulo responde, cuja voz discreta

O Mauritano sábio lhe interpreta:

- «Estas figuras todas que aparecem,

Bravos em vista e feros nos aspeitos, 
Mais bravos e mais feros se conhecem,

Pela fama, nas obras e nos feitos.

Antigos são, mas inda resplandecem

Co nome, entre os engenhos mais perfeitos.

Este que vês, é Luso, donde a Fama

O nosso Reino «Lusitânia» chama.

«Foi filho e companheiro do Tebano

Que tão diversas partes conquistou;

Parece vindo ter ao ninho Hispano

Seguindo as armas, que contino usou.

Do Douro, Guadiana o campo ufano,

Já dito Elísio, tanto o contentou

Que ali quis dar aos já cansados ossos

Eterna sepultura, e nome aos nossos.

«O ramo que lhe vês, pera divisa,

$\mathrm{O}$ verde tirso foi, de Baco usado;

$\mathrm{O}$ qual à nossa idade amostra e avisa

Que foi seu companheiro e filho amado.

Vês outro, que do Tejo a terra pisa,

Despois de ter tão longo mar arado,

Onde muros perpétuos edifica,

E templo a Palas, que em memória fica?

«Ulisses é, o que faz a santa casa

À Deusa que lhe dá língua facunda;

Que se lá na Ásia Tróia insigne abrasa,

Cá na Europa Lisboa ingente funda.»

- «Quem será estoutro cá, que o campo arrasa

De mortos, com presença furibunda?

Grandes batalhas tem desbaratadas,

Que as Águias nas bandeiras tem pintadas!»

Assi o Gentio diz. Responde o Gama:

- «Este que vês, pastor já foi de gado;

Viriato sabemos que se chama,

Destro na lança mais que no cajado;

Injuriada tem de Roma a fama,

Vencedor invencíbil, afamado.

Não tem com ele, não, nem ter puderam,

O primor que com Pirro já tiveram. 
«Com força, não; com manha vergonhosa

A vida lhe tiraram, que os espanta;

Que o grande aperto, em gente inda que honrosa,

Às vezes leis magnânimas quebranta.

Outro está aqui que, contra a pátria irosa,

Degradado, connosco se alevanta;

Escolheu bem com quem se alevantasse

Pera que eternamente se ilustrasse.

«Vês, connosco também vence as bandeiras

Dessas aves de Júpiter validas;

Que já naquele tempo as mais guerreiras

Gentes de nós souberam ser vencidas.

Olha tão sutis artes e maneiras

Pera adquirir os povos, tão fingidas:

A fatídica cerva que o avisa.

Ele é Sertório, e ela a sua divisa (VIII, 1-8).

Hernâni Cidade analisa perfeitamente a estratégia de se listarem como antecessores dos heróis figuras da cultura clássica:

Começa ela [a galeria de guerreiros] nos tempos mitológicos, que para o Poeta, como para os historiógrafos e eruditos do século XVI e XVII, a história sem protesto anexava. André de Resende ou Fr. Bernardo de Brito incluíam igualmente, entre os reis peninsulares, Baco e Luso, além de Hércules e Brigo; e para todos Ulisses fora o fundador de Lisboa (1968, p. 168).

Observe-se que, para além dessa tradição de remontar eruditamente a genealogia de uma nação à mitologia, parece estar em pauta também nessa estratégia discursiva a adesão de Camões à lei do gênero épico, consagrada por Homero e Virgílio, cujos protagonistas entroncam sua ascendência na prole dos mitos ou das lendas.

Em seguida aos heróis fabulosos, são apresentados os homens históricos menos remotos, mas com aura de patriarcas fundadores e sagrados, o Conde D. Henrique ("À Casa Santa passa o santo Henrique") e o rei Afonso Henriques ("Este é aquele zeloso a quem Deus ama”):

«Olha estoutra bandeira, e vê pintado

O grão progenitor dos Reis primeiros:

Nós Húngaro o fazemos, porém nado

Crêm ser em Lotaríngia os estrangeiros.

Despois de ter, cos Mouros, superado

Galegos e Lioneses cavaleiros,

À Casa Santa passa o santo Henrique, 
Por que o tronco dos Reis se santifique.»

- «Quem é, me dize, estoutro que me espanta

(Pergunta o Malabar maravilhado),

Que tantos esquadrões, que gente tanta,

Com tão pouca, tem roto e destroçado?

Tantos muros aspérrimos quebranta,

Tantas batalhas dá, nunca cansado,

Tantas coroas tem, por tantas partes,

A seus pés derribadas, e estandartes?»

- «Este é o primeiro Afonso (disse o Gama),

Que todo Portugal aos Mouros toma;

Por quem no Estígio lago jura a Fama

De mais não celebrar nenhum de Roma.

Este é aquele zeloso a quem Deus ama,

Com cujo braço o Mouro imigo doma,

Pera quem de seu Reino abaxa os muros,

Nada deixando já pera os futuros.

«Se César, se Alexandre Rei, tiveram

Tão pequeno poder, tão pouca gente,

Contra tantos imigos quantos eram

Os que desbaratava este excelente,

Não creias que seus nomes se estenderam

Com glórias imortais tão largamente;

Mas deixa os feitos seus inexplicáveis,

Vê que os de seus vassalos são notáveis (VIII, 9-12),

para, finalmente, serem enaltecidos os “valerosos” (destacados em itálico):

«Este que vês olhar, com gesto irado,

Pera o rompido aluno mal sofrido,

Dizendo-lhe que o exército espalhado

Recolha, e torne ao campo defendido;

Torna o Moço, do velho acompanhado,

Que vencedor o torna de vencido:

Egas Moniz ${ }^{16}$ se chama o forte velho,

Pera leais vassalos claro espelho (VIII, 13).

16 Escusamo-nos de comentar e ilustrar o valor de cada um desses homens na história portuguesa em função da economia deste artigo. 
É Dom Fuas Roupinho, que na terra

E no mar resplandece juntamente,

Co fogo que acendeu junto da serra

De Ábila, nas galés da Maura gente [...] (VIII, 17).

«Não vês um ajuntamento, de estrangeiro

Trajo, sair da grande armada nova,

Que ajuda a combater o Rei primeiro

Lisboa, de si dando santa prova?

Olha Henrique [de Bonn], famoso cavaleiro,

A palma que lhe nasce junto à cova [...] (VIII, 18).

«Um Sacerdote vê, brandindo a espada

Contra Arronches, que toma, por vingança

De Leiria, que de antes foi tomada

Por quem por Mafamede enresta a lança:

É Teotónio Prior. [...] (VIII, 19).

[...] Mem Moniz é, que em si o valor retrata

Que o sepulcro do pai cos ossos cerra (VIII, 20).

[...] Giraldo Sem Pavor é o forte peito (VIII, 21).

«Martim Lopes se chama o cavaleiro

Que destes levar pode a palma e o louro [...] (VIII, 23).

[...] Vês? Já a vila de Alcácere se humilha,

Sem lhe valer defesa ou muro de aço,

A Dom Mateus, o Bispo de Lisboa,

Que a coroa de palma ali coroa (VIII, 24).

«Vês, com bélica astúcia ao Mouro ganha

Silves, que ele ganhou com força ingente:

É Dom Paio Correia, cuja manha

E grande esforço faz enveja à gente [...] (VIII, 26).

[...] Que o principal dos três desafiaram,

Que Gonçalo Ribeiro se nomeia,

Que pode não temer a lei Leteia (VIII, 27). 
[...] «Se quem com tanto esforço em Deus se atreve

Ouvir quiseres como se nomeia,

«Português Cipião» chamar-se deve;

Mas mais de «Dom Nuno Álvares» se arreia.

Ditosa pátria que tal filho teve! [...] (VIII, 32).

«Olha cá dous Infantes, Pedro e Henrique,

Progénie generosa de Joane; [...] (VIII, 37).

«Vês o Conde Dom Pedro [de Meneses], que sustenta

Dous cercos contra toda a Barbaria.

Vês, outro Conde [Duarte de Menezes] está, que representa

Em terra Marte, em forças e ousadia [...] (VIII, 38).

«Outros muitos verias, que os pintores

Aqui também por certo pintariam;

Mas falta-lhe pincel, faltam-lhe cores:

Honra, prémio, favor, que as artes criam.

Culpa dos viciosos sucessores,

Que degeneram, certo, e se desviam

Do lustre e do valor dos seus passados,

Em gostos e vaidades atolados (VIII, 39).

Como afirma Jorge de Sena, a escolha e a sequência das figuras representadas nas bandeiras resulta numa "teoria genealógica e nobiliárquica do mérito adquirido pela linhagem" (1980, p. 47) e revela, em termos estritos,

Que de tudo isso tenha nascido um poema extraordinário (em que os amigos, os familiares, os grandes que protegiam uns e outros, são louvados por si ou por seus antepassados), eis o que releva do génio [Camões]. Mas esta palavra é ainda romântica, ou pode sê-lo, e [pode] obnubilar-nos que este génio resultou da sua própria situação existencial de pequeno nobre sem eira nem beira, envolvido por condição numa aventura gigantesca que determina a sua visão da História, aventura que tinha sido e era obra precisamente dos filhos segundos e dos ramos segundos (já que os chefes das grandes casas raro saíram, no século XVI, dos remansos de suas casas e das suas rendas, ou do serviço directo dos reis), um dos quais rebentos ele mesmo era. Camões escreveu para cantar e glorificar esse seu mundo e para celebrar-se a si mesmo compensatoriamente: que o poema se tenha tornado nacional foi obra do espírito senhorial da nossa história portuguesa [...]" (SENA, 1980, p. 50).

Antes, porém, e em termos de análise textualista, trata-se de uma genealogia encarecedora das raízes portuguesas, baseadas eruditamente na mitologia grega (Ulisses, fundador de Lisboa 
[“Cá na Europa Lisboa ingente funda”]) e na cultura latina, Viriato e Sertório, rebeldes romanos. ${ }^{17}$ A historicidade pré-portuguesa destes últimos contrasta com o caráter mítico daqueles Luso e Ulisses - como de resto contrasta uma série de aspectos de Os Lusíadas, expressa no plano duplo da epopeia camoniana, histórico e mitológico, eixo do poema. O resultado dessa listagem mítico-histórica de heróis individuais é o elogio dos homens eminentemente históricos que lhe seguirão: o Conde Dom Henrique de Borgonha e seu filho Afonso Henriques, patriarcas de Portugal. Só assim se explica - e se elogia - a verve dos "valerosos" que Paulo da Gama passará a apresentar ao Catual.

A lista de nomes se destaca pelo fato de serem homens leais aos reis de Portugal. Alguns deles são referidos no Canto III e IV, como Egas Moniz (III, 35-40) e Nuno Álvares (IV, 14-24). A nova referência no Canto VIII redimensionaria esses guerreiros, dando-lhes, como observamos, o heroísmo individualizado de guerreiros na narração de Paulo da Gama, como pensou Jorge de Sena:

O Canto VIII tem a sua primeira metade ocupada com a descrição das bandeiras, em que é mitificada como heroísmo individualizado (mas ainda não transfigurado, o que só cabe ao [Vasco da] Gama) a História anterior [às navegações], que não havia sido narrada pelo mesmo Gama (1980, p. 74) ${ }^{18}$.

Um outro aspecto ainda vem ao encontro da tese da importância estrutural de Paulo da Gama na narrativa camoniana: considerada a centralidade do Narrador $_{1}$ (a se ocupar de todo o poema) e as duas partes em que se divide o poema, Vasco da Gama seria o narrador da primeira parte, que, nas terras africanas, rememoraria de coeur os feitos régios portugueses em nome do rei Dom Manuel; em paralelo e em correspondência, na segunda parte, Paulo descreveria e explicaria por meio de pinturas os feitos vassálicos lusitanos em nome do capitão-mor Vasco, ausente na capitânia durante a visita do Catual. Assim, para as duas partes, dois narradores com funções idênticas (expor à curiosidade do rei de Melinde e do Catual hindu as gestas que deram fama aos de Luso) e hierarquicamente (capitão-mor e capitão) concebidas para a arquitetura da epopeia.

Vale ainda lembrar que o uso de um terceiro narrador, que equilibra a narrativa, está também prefigurada na principal epopeia-modelo de Camões, a Eneida (2014). Também lá, para além do Narrador $_{1}$ (narrador épico heterodiegético), presente na maior parte da narrativa, e do Narrador (narrador homodiegético e autodiegético), Eneias, responsável por grande parte dos Cantos II e III, em que o passado de Troia - e, por conseguinte, de Roma - é rememorado, encontra-se um Narrador $_{3}$, heterodiegético: Anquises, que toma mais de duzentos versos do Canto VI, episódio fundamental da arquitetura narrativa do poema. ${ }^{19}$ Os paralelos entre as falas de Paulo da Gama

17 Cf. os verbetes de João Franco Barreto a respeito dessas personagens (1982, p. 710-711 [Sertório]; p. 787-788 [Viriato])

18 Ainda que em se tratando de vassalos, subservientes, portanto, ao poder régio que torna suas vontades coletivas, como pondera Luís de Oliveira e Silva a respeito, por exemplo, de Vasco da Gama (2011, p. 397-398).

19 Putnam (1995), entre muitos outros, acredita que a narração de Anquises no Canto VI da Eneida representa a base filosófica do poema. Para uma discussão acerca da arquitetura da Eneida, e do Canto VI como fundamental, cf. Williams (1990) e Perkell (1999). 
e de Anquises são vários: ambas são figurativas e ecfrásticas; ambas são mais alusivas do que informativas; ambas têm como ênfase a honra de seus feitos e a glória em batalha, em geral representadas por símbolos (a coroa de carvalhos, o ramo de oliveira, os spolia opima em Anquises; o verde tirso, as aves de Júpiter, as coroas derribadas em Paulo da Gama); ambas são, em resumo, uma sucessão cronológica de grandes homens e seus grandes feitos. Certo é que em Camões os fatos são passados e em Vergílio, é o futuro de Eneias que se descortina pelas palavras de Anquises; mas fato é que, para os leitores romanos, aquelas façanhas eram o seu próprio passado heroico, narrado a partir das figuras dos numes que se sucedem em procissão ante os olhos de Eneias, tão inscientes como os do Catual.

A leitura de Cleonice Berardinelli, "[per]clara em sua geração”, ensejou-nos ensaiar uma contribuição que, esperamos, redimensione a percepção dos papeis dos narradores de Os Lusíadas. Considerando a complexa e minuciosa "arquitetura significativa" que Jorge de Sena brilhantemente observou no poema, uma proposição tripartite não poderia deixar de projetar no eixo narrativo da epopeia o tríptico eminente de narradores a assegurar o arrojado canto que espalhe por toda parte "engenho e arte".

\section{Referências}

AMES, Glenn J. Background to the Voyage. In: GAMA, Vasco da (?). Em nome de Deus: The Journal of the First Voyage of Vasco da Gama to India. Leiden: Brill, 2009

ANDRETTA, Stefano. La realtà iberica nelle opere di Giovanni Pietro M. e Giovanni Botero. In: A COMPANHIA DE JESUS NA PENÍNSULA IBÉRICA NOS SÉCS. XVI E XVII: espiritualidade e cultura. Colóquio Internacional do Centro Interuniversitário de História da Espiritualidade, 2, 2004. Porto. Actas... Porto: Humbertipo, 2005. p. 519-542.

BARRETO, João Franco. Micrologia camoniana [1672]. Lisboa: Imprensa Nacional-Casa da Moeda, 1982.

BEHR, Francesca D’Alessandro. The Narrator's Voice: a Narratological Reappraisal of Apostrophe in Virgil's Aeneid, Arethusa, Baltimore, v. 38, n. 2, p. 189-221, Spring 2005.

BERARDINELLI, Cleonice. A estrutura d'Os lusíadas. Os excursos do poeta n'Os lusíadas. In: . Estudos camonianos. Nova edição revista e ampliada. Rio de Janeiro: Nova Fronteira, 2000. p. 15-30 (Estrutura); p. 31-55 (Excursos).

CAMÕES, Luís de. Os lusíadas. Edição coordenada por Gladstone Chaves de Melo et al. Rio de Janeiro: Ministério da Educação e Cultura, 1972.

. Os lusíadas. Edição de Emanuel Paulo Ramos. 3. ed. Porto: Porto, [s. d.].

. Os lusíadas. Fac-símile das duas edições de 1572. Lisboa: Imprensa Nacional-Casa da Moeda, 1982.

. Os lusíadas. Rio de Janeiro: Biblioteca do Exército, 1999. 
- Os lusíadas. Prefácio de Álvaro Júlio da Costa Pimpão. Apresentação de Aníbal Pinto de Castro. 4. ed. Lisboa: Ministério dos Negócios Estrangeiros; Instituto Camões, 2000. Disponível em: <http://cvc.instituto-camoes.pt/conhecer/biblioteca-digital-camoes/explorar-por-autor. html?aut=182>. Acesso em: 1 ago. 2016.

CASTANHEDA, Fernão Lopes de. História do descobrimento \& conquista da India pelos portugueses. Coimbra, [s. ed.], 1552. v. 1. Disponível em: <http://purl.pt/15294>. Acesso em: 3 fev. 2017. História do descobrimento \& conquista da India pelos portugueses. Nova edição. Lisboa: Rollandiana, 1833. v. 1. Disponível em: <https://play.google.com/books/reader?id=_xBBAQAAMAAJ\&printsec $=$ frontcover\&output=reader\&hl=pt_BR\&pg=GBS.RA1-PA6>. Acesso em: 9 jul. 2017.

CIDADE, Hernâni. A substância épica n’Os lusíadas: os heróis e a Nação. In: Luís de Camões: o épico. 3. ed. corrigida e ampliada. Amadora: Bertrand, 1968. p. 167-176.

CUNHA, Antônio Geraldo da. Índice analítico do vocabulário de Os Lusíadas. 2. ed. Rio de Janeiro: Presença, 1980.

FOWLER, Don. Deviant Focalisation in Virgil's Aeneid. In: HARDIE, Philip. Virgil. London; New York: Routledge, 1999. v. 3. p. 302-23.

HOUAISS, Antônio; VILLAR, Mauro de Salles. Dicionário Houaiss da língua portuguesa. Rio de Janeiro: Objetiva, 2001.

MAFFEI, Giovanni Pietro (Iohannes Petrus Maffeius). Historiarum Indicarum Libri XVI. Lugdunum: Officina Iunctarum, 1589.

PERKELL, Christina (Ed.). Reading Vergil's Aeneid: an interpretive guide. Norman: Oklahoma University, 1999.

PIMPÃO, Álvaro Júlio da Costa. Notas. In: CAMÕES, Luís de. Os lusíadas. Prefácio e notas de Álvaro Júlio da Costa Pimpão. Apresentação de Aníbal Pinto de Castro. 4. ed. Lisboa: Ministério dos Negócios Estrangeiros; Instituto Camões, 2000. Disponível em: <http://cvc.instituto-camoes. pt/conhecer/biblioteca-digital-camoes/explorar-por-autor.html?aut=182>. Acesso em: 1 ago. 2016. PINHO, Sebastião Tavares de. A descrição camoniana da Europa e a cartografia ginecomórfica, Revista Camoniana, Bauru, s. 3, v. 14, p. 185-228, 2003.

PUTNAM, Michael. Virgil's Aeneid: interpretation and Influence. Chapel Hill: University of North Carolina, 1995.

REIS, Carlos; LOPES, Ana Cristina. Dicionário de teoria da narrativa. São Paulo: Ática, 1988. SARAIVA, António José. Ut pictura poesis. Função e significado do maravilhoso n’Os Lusíadas. In: Estudos sobre a arte d'Os lusíadas. Lisboa: Gradiva, 1996. p. 77-90; p. 111-121.

SARAIVA, António José. Ut pictura poesis. Função e significado do maravilhoso n’Os Lusíadas. In: Estudos sobre a arte d'Os lusíadas. Lisboa: Gradiva, 1996. p. 77-90; p. 111-121.SENA, Jorge de. Camões e a estrutura de Os Lusíadas. In: A estrutura de Os Lusíadas e outros estudos camonianos e de poesia peninsular do séc. XVI. Lisboa: Edições 70, 1980. p. 17-176. 
. Estudos sobre o vocabulário de Os Lusíadas com notas sobre o humanismo e o exotismo de Camões. Lisboa: Edições 70, [1982].

SILVA, Luís de Oliveira e. Autor e narrador n’Os lusíadas. Gama, Vasco da. In: SILVA, Vítor Aguiar e (Coord.). Dicionário Luís de Camões. São Paulo: Leya, 2011. p. 54-57 (Autor); p. 395-400 (Gama). SILVA, Vítor Aguiar e (Coord.). Dicionário Luís de Camões. São Paulo: Leya, 2011.

Baco. In: (Coord.). Dicionário Luís de Camões. São Paulo: Leya, 2011. p. 59-63. SILVA, Vítor Manuel de Aguiar e. O romance: história e sistema de um género literário. In:

Teoria da literatura. 8. ed. Coimbra: Almedina, 2007. p. 671-786.

VIRGÍlIO. Eneida. Trad. Carlos Alberto Nunes. São Paulo: Editora 34, 2014.

WILLIAMS, R. D. The Sixth Book of the Aeneid. In: HARRISON, Stephen (Ed.). Oxford Readings of Vergil's Aeneid. Oxford: Oxford University, 1990. p. 191-207.

\section{Minicurrículos}

Paulo Roberto Sodré é professor doutor de Literatura Portuguesa no Departamento de Línguas e Letras e no Programa de Pós-graduação em Letras do Centro de Ciências Humanas e Naturais da Universidade Federal do Espírito Santo. Realizou estágio pós-doutoral na Unicamp em 2007. Autor de Um trovador na berlinda: as cantigas de amigo de Nuno Fernandes Torneol (São Paulo: Íbis, 1998), Cantigas de madre galego-portuguesas: estudo de xéneros das cantigas líricas (Santiago de Compostela: R Piñeiro, 2008) e O riso no jogo e o jogo no riso na sátira galego-portuguesa (Vitória: Edufes, 2010), e escritor, autor de De Ulisses a Telêmacos e outras epistolas (1998) e Poemas desconcertantes (2017), dentre outros.

Leni Ribeiro Leite é doutora em Letras Clássicas pela Universidade Federal do Rio de Janeiro, com estágio pós-doutoral na University of Kentucky, junto ao Institutum Studiis Latinis Provehendis. É professora de Língua e Literatura Latina na Universidade Federal do Espírito Santo, credenciada como permanente no Programa de Pós-Graduação em Letras e no Programa de Pós-Graduação em História da mesma instituição. É bolsista de produtividade em pesquisa (Bolsa Pesquisador Capixaba 2016-2018) pela Fundação de Amparo à Pesquisa do Espírito Santo, e autora, entre outros, de Marcial e o Livro (Vitória: Edufes, 2013) e Épica II: Ovídio, Lucano, Estácio (Campinas: Unicamp, 2016). 